\title{
THE POLITICS OF MEDICINE IN MANCHESTER, 1788-1792: HOSPITAL REFORM AND PUBLIC HEALTH SERVICES IN THE EARLY INDUSTRIAL CITY
}

\author{
by
}

\author{
J. V. PICKSTONE and S. V. F. BUTLER*
}

\begin{abstract}
The affairs of the Infirmary and Lunatic Hospital continued till Michaelmas 1790 when a particular scrutiny was made into the Rules and Government of the Charities; and so many additions and alterations made in them that almost an entire New System was introduced. Six Physicians and Six Surgeons were then appointed to manage the whole business of their profession. Compleat Assistance was provided for the Poor in every Malady to which they are Subject and for which the Art of Man has yet found a remedy. ${ }^{1}$
\end{abstract}

BY 1790, the Manchester Infirmary had existed for almost forty years. It had been founded in 1752, one of a series of voluntary hospitals which had spread across the provinces in the 1750s and 1760s. ${ }^{2}$ They were the central charities in increasingly prosperous towns, means by which leading citizens could demonstrate a collective responsibility for the poor, and arenas in which physicians and the better-qualified surgeons could establish a public presence and demonstrate their skills. In 1780, there was little to distinguish Manchester's Infirmary from those in many county towns, which were to continue little changed for a century or so.

The Infirmary revolution of 1790 came about because Manchester had begun to change rapidly. The 1780s saw a large inflow of capitalists and labourers, and with them came professional men, including Scottish-trained physicians anxious to use their scientific training to create successful careers among the rising bourgeoisie. Such men, together with the educated sons of established merchants, formed a radical group within the cultural circle of older Whig reformers. We shall argue in this paper that the Infirmary revolution was the major local success of these radicals before they were dispersed by the counter-revolutionary pressures of the 1790s. To do so, we set the history of the hospital firmly within the history of the town, and we examine in the history of Manchester a cluster of national political campaigns - about slavery, Dissenters' rights, and the Regency crisis. Arnold Thackray, in his study of the early

*J. V. Pickstone, PhD, Department of History of Science and Technology. University of Manchester Institute of Science and Technology; and S. V. F. Butler, PhD, Greater Manchester Museum of Science and Industry.

${ }^{1}$ C. Bayley, A sermon preached in the Collegiate Church of Manchester, Manchester, 1792, pp. 6-7.

2 For a list of Infirmary foundations, see John Woodward, To do the sick no harm; a study of the British voluntary hospital system to 1875, London, Routledge \& Kegan Paul, 1974, pp. 147-148. The major secondary sources for the Manchester Infirmary are: W. Brockbank, Portrait of a hospital 1752-1948. London, Heinemann, 1952; and F. Renaud, $A$ short history of the rise and progress of the Manchester Royal Infirmary from the year 1752 to 1877. Manchester, Cornish, 1898. For a discussion of the relationship between the development of industrialism and the hospital movement see $C$. Webster, 'The crisis of the hospitals during the Industrial Revolution', in E. G. Forbes (editor), Human implications of scientific advance. Edinburgh University Press, 1978, pp. 214-233. 


\section{J.V. Pickstone and S. V.F. Butler}

years of the Manchester Literary and Philosophical Society, ${ }^{3}$ has shown how much can be gained from such a local study. Our focus is sharper still; we are concerned primarily with one hospital over four years. But the hospital was then the major voluntary institution in Manchester, and Manchester in 1790 was significant on a global scale.

The paper is divided into three portions. In the first we describe the Infirmary in the 1780s, placing it in the urban context of that boom decade. Next, we describe in detail the course of the revolution in and around 1790. Finally, we consider more fully the parts which various religious denominations played in these events, linking the revolution to the health politics of the 1790s, especially the Board of Health and House of Recovery of 1796.

\section{MANCHESTER AND ITS INFIRMARY IN THE 1780s}

Officially, Manchester in 1780 was little more than a village, though its population was close to 50,000. The Lord of the Manor was John Mosley. His Steward presided over a Court Leet which elected several honorary officers, including the Borough reeve and constables. The Court also elected a number of paid officials to whom the bulk of the day-to-day work was devolved. Effective control of this system lay with a group of High Church Tories associated with Mosley and the Collegiate Church. In the 1780s, the Court and its officers were often both slack and incompetent. ${ }^{5}$

This Tory dominance had been challenged but it was persistent. In 1731 and again in 1763, local reforms advocated by Whigs had been blocked. ${ }^{6}$ Even so, some individual Whigs did hold considerable power. Thomas Butterworth Bayley, brought up as a Presbyterian and later a trustee of Cross Street Unitarian Chapel, was for many years the leading local magistrate and a keen student of prisons and workhouses.' But Bayley's mother came from a gentry family and he drifted towards the Church. Though a reformer, he was hardly a radical. The Whigs found their major civic role in the voluntary associations of Manchester. Bayley supported the Agricultural Society of 1767, and the Academy in nearby Warrington. His friend, Thomas Percival, MD, was the chief founder of the Manchester Literary and Philosophical Society (1781). In 1774, Percival had helped to establish a small hospital for venereal disease patients. He had tried to reform systems of registration (the Bills of Mortality), and had sponsored an enumeration of Manchester.

The scale of voluntary activity increased rapidly during the early 1780 s. In 1783 , the

${ }^{3}$ A. Thackray, 'Natural knowledge in cultural context, the Manchester model', Amer. hist. Rev., 1974, 79: 672-709.

J. Aston, A picture of Manchester, Manchester, 1816, pp. 21-26.

${ }^{3} \mathrm{~S}$. and B. Webb, The parish and the county. English local government. Series I,. London, Longmans, 1906, pp. 72-76; A. Redford, The history of local government in Manchester, vol. 1, London, Longmans, 1939, p. 192.

6 S. and B. Webb, op. cit., note 5 above, p. 72. See also, G. B. Hindle, Provision for the relief of the poor in Manchester, 1754-1826, Manchester University Press, 1975, p. 20.

' For a biographical sketch see T. Baker, Memorials of a dissenting chapel, London, 1884, p. 87. See also, T. Percival, Biographical memoirs of Thomas Butterworth Bayley, Manchester, 1802.

- Percival was Manchester's most distinguished physician of the late eighteenth century. For biographical details see the memoir in Percival's Works, literary, moral and medical, vol. I, Bath, 1807; R. B. Hope, 'Dr Thomas Percival: a medical pioneer and social reformer, 1740-1804'. MA thesis. University of Manchester, 1947. 
Literary and Philosophical Society sponsored a short-lived College of Arts and Science.' In 1786, a Dissenting Academy was founded in elegant premises in Manchester. ${ }^{10}$ Although it was dominated by Dr Thomas Barnes, the Unitarian minister, its courses were non-denominational. Indeed, the early 1780 s were marked by considerable ecumenism. The Manchester Sunday Schools, founded in 1784, were supported by Nonconformists and Catholics as well as by Anglicans. ${ }^{11}$ Though the Literary and Philosophical Society had first met in Cross Street Chapel, its early membership included several Anglican ministers. It was within this culture, of a commercial town prosperous enough to invite national attention, that major developments took place at the Manchester Infirmary.

By 1780 , the Infirmary was already a complex institution. The original building of 1755 was surrounded by tasteful gardens and fashionable walks. In 1763, a Lunatic Hospital had been added ${ }^{12}$ - the second in the provinces to be attached to a general voluntary hospital. It housed pauper lunatics, paid for by overseers, and some from the middle classes, paid for by their families. From 1779, on ground to the north of the Infirmary, the Trustees added a range of public baths: cold, Buxton, warm, and vapour. It was "one of the most complete and elegant sets of baths in the kingdom", ${ }^{13}$ designed for middle-class subscribers rather than for patients, who had separate facilities. Both the Lunatic Hospital and the Baths were popular and profitable.

The Infirmary itself was an attractive means of philanthropy. It was less subject to abuse than non-medical charities and could not be regarded as encouraging laziness. Its subscribers' recommendations brought the sick poor into a well-regulated public household. No one expected that such hospitals would appreciably improve the health of the general population. They were intended to furnish patients with "Diet, washing and lodging"; "medicines were dispensed, nurses provided"; patients were "supplied with everything during their sickness, to promote a speedy recovery". ${ }^{14}$

By 1780 , the day-to-day control of the Infirmary lay increasingly with its surgeons. One of them, Charles White, ${ }^{15}$ had a national reputation. As a young man, when newly returned home after study in London, he had helped to found the Infirmary. His father, Thomas White, in whose practice he had learned his craft, had also been a member of the initial staff. A second family of Manchester surgeons, the Halls, were likewise well represented at the Infirmary. Edward Hall had served with Charles White from $1752 .{ }^{16}$ His son Richard was appointed in 1779, when the third founding

\footnotetext{
- T. Barnes, 'Proposals for establishing in Manchester a plan of liberal education, for young men designed for civil and active life, whether in trade or in any of the professions', Mem. Manchester Lit. Philos. Soc., 1789, 2: 30-46.

$10 \mathrm{G}$. M. Ditchfield, 'The early history of the Manchester College', Trans. Hist. Soc. Lancashire and Cheshire, 1972, 123: 81-104. Also J. F. Fulton, 'The Warrington Academy (1757-1786), and its influence upon medicine and science', Bull. Inst. Hist. Med., 1933, 1: 50-80.

"A. P. Wadsworth, 'The first Manchester Sunday schools', in M. W. Flinn and T. C. Smout (editors), Essays in social history, Oxford, Clarendon Press, 1974, pp. 100-122.

12 Brockbank, op. cit., note 2 above, p. 21.

13 Ibid., p. 26.

14 Ibid., p. 6.

15 E. M. Brockbank, The honorary medical staff of the Manchester Infirmary, 1752-1830, Manchester University Press, 1904, pp. $26-65$.

16 Ibid., pp. 9-12.
} 


\section{J. V. Pickstone and S. V. F. Butler}

surgeon was forced out as unfit to perform his duties. ${ }^{17}$ This nepotism and "surgical monopoly" was publicly criticized, ${ }^{18}$ for Infirmary appointments, albeit honorary, were much prized, especially by surgeons. They were the mark of the skill and experience looked for by wealthier patients. They also attracted apprentices, who paid large fees to masters with access to Infirmary practice.

Of the three honorary physicians in 1780 , two had served since 1752; but they were older than the surgeons and no longer equal to the demands of the Infirmary positions. Peter Mainwaring, ${ }^{19}$ an Anglican graduate of Cambridge, was a magistrate who later served as a president of the Literary and Philosophical Society; Samuel Kay ${ }^{20}$ was a Dissenter and an Edinburgh graduate. They were cultured professional men in a prosperous town, but neither was noted for writing or for developments at the Infirmary. These distinctions fell to Percival, even before he became a member of the Infirmary staff.

In 1779, Percival was elected an honorary physician in the place of Philip Brown, ${ }^{21}$ who had served from 1758. Percival had been educated at Warrington Academy and at Edinburgh, London, and Leiden. The early death of his London patron, Lord Willoughby de Parham, had caused him to return to the north in 1767, and to develop his practice among the merchants of Manchester. Percival was a key member of the national network of Dissenting intellectuals. When John Aikin, the son of Percival's Warrington tutor, produced his Thoughts on hospitals (1771), he included a short essay by Percival on hospital regulations. ${ }^{22}$

The work was representative of the concern with cleanliness and ventilation that was then widespread. Commentators on prisons, like Stephen Hales, and on military medicine, like Pringle and Lind, had raised these issues in discussing the distress and costs of fever. ${ }^{23}$ Percival wrote of "air, diet and medicines" as the three great agents to be employed in preventing and correcting putrefaction and contagion in hospitals. Cleanliness and discipline were measures especially favoured by Dissenters, but not by them alone. Charles White, an Anglican, to whom young Aikin had once been apprenticed, wrote a treatise on midwifery in 1773.24 Against the cosseting of women and children as practised by female midwives, he advocated more activity, fewer clothes, and better ventilation as ways of preventing puerperal fever.

In spite of this established interest in hospitals, Percival did not long remain an Infirmary physician. After little more than a year, in October 1780, he resigned for he had "neither the strength of constitution nor the leisure from the necessary duties of life to fulfil with fidelity the trust reposed in him". ${ }^{25}$ Yet his tenure was not without

\footnotetext{
17 Minutes of the Manchester Infirmary Quarterly Board, 14 January 1779.

18 Letter from Burchall, Manchester Mercury, 12 January 1779.

19 Brockbank, op. cit., note 15 above, pp. 17-21.

20 Ibid., pp. 22-25.

21 Ibid., pp. 69-71.

22 This essay is included in Percival, Works, op. cit., note 8 above, vol. 4, pp. 170-179.

${ }^{23} \mathrm{M}$. C. Buer, Health, wealth and population in the early days of the Industrial Revolution, London, Routledge, 1926, pp. 118-125.

${ }^{24} \mathrm{C}$. White, $A$ treatise on the management of pregnant and lying-in women, and the means of curing, but more especially of preventing the principal disorders to which they are liable, London, 1773.

${ }^{25}$ Percival's letter, dated 29 October 1780, was reproduced in the Manchester Mercury, 7 November
} 1780 . 
consequences. Because neither he nor his aged colleagues were equal to the work, he had persuaded them that help would be better obtained by recruiting assistants than by relying on the house apothecary and apprentices. ${ }^{26}$ Four young practitioners had been appointed - Wright, Cowling, Mitchell, and Stapleton - none of whom had any previous connexion with the Infirmary. Two of these men competed for the position Percival vacated. Wright, an ex-army surgeon, was elected but soon quarrelled with his colleagues and was dismissed. ${ }^{27} \mathrm{He}$ was succeeded as assistant physician by George Bell, ${ }^{28}$ a protégé of Percival and a close friend of James Currie, who was then attracting attention as a Dissenting physician in Liverpool. ${ }^{29}$

By 1780 , then, we can see characteristic differences in professional patterns between the two sides of the Infirmary staff. The surgical practice was dominated by two local family businesses. On the medical side, around the old physicians from local families, hovered a number of immigrant doctors, mostly ex-army or Edinburgh graduates. The latter, especially, joined the intellectual coteries around the Literary and Philosophical Society. They were also keen to secure places in the Infirmary.

In 1781, the assistant physicians (and Wright) suggested that patients who were suffering from fever or other contagious disorders should be attended at their own homes. ${ }^{30}$ This was the beginning of the home-patient service and the first major involvement of the Infirmary with public health issues. The Manchester home-patient service meant that the Infirmary also fulfilled the function of a Dispensary, an unusual combination. Though Dispensaries spread through the country in the final two decades of the century as Infirmaries had in the middle decades, they were usually separate institutions, even in towns which already had an Infirmary. ${ }^{31}$ In Liverpool, for example, an independent Dispensary was set up in 1778 to provide out-patient and home-patient services.

The concern of early Dispensary doctors with the condition of the poor was the civilian medical counterpart to the stress on cleanliness and order in military and penal establishments. Edinburgh-trained doctors were conspicuous in both spheres, partly because of their technical training, partly because most of them were Dissenters reared to personal discipline and regimen, and to see health "as a means to vocation". The aims and accomplishments of Dispensaries would be well known to Manchester doctors, and the close friendship between Bell and Currie in Liverpool may have been crucial. For ambitious young assistants, offering to extend the services of the charity was a means of increasing their chances of promotion when honorary posts fell vacant. In 1782, on the retirement of Kay and Mainwaring and after Wright's dismissal, Bell, Eason, and Cowling were made full physicians. ${ }^{32}$

\footnotetext{
26 Minutes of the Manchester Quarterly Board, 23 March 1780.

${ }^{27}$ Ibid., 21 December 1781. For details of the disputes see Manchester Mercury, 26 March 1782.

28 For biographical details see Brockbank, op. cit., note 15 above, pp. 115-117. Also the menıoir by James Currie in Mem. Manchester Lit. Philos. Soc., 1789, 2: 397-409.

${ }^{29}$ William Wallace Currie (editor), Memoir of the life, writings and correspondence of James Currie of Liverpool, London, 1831.

${ }^{30}$ Minutes of the Manchester Infirmary Quarterly Board, 23 August 1781.

31 I. S. L. Loudon, 'The origins and growth of the dispensary movement in England', Bull. Hist. Med., 1981, 55: 322-342; J. V. Pickstone, 'What were dispensaries for? The Lancashire foundations during the Industrial Revolution' [abstract], Bull. Soc. soc. Hist. Med., 1977, 20: 25-28.

32 Minutes of the Manchester Infirmary Annual Board, 20 June 1782.
} 
A similar pattern was repeated in 1784 when Drs Chorley and Latham offered to provide free inoculation for the poor, as advocated and demonstrated in Chester by Percival's friend, John Haygarth. ${ }^{33}$ The Trustees welcomed the offer, and Chorley and Latham later both became full physicians. But even in the early 1780 s, when neither local politics nor medical rivalries were intense, not all suggested innovations proved acceptable. In 1783, Bell had proposed that part of the Infirmary grounds be used as a garden for medicinal plants, both to supply the apothecary's shop and to allow experimentation by the honorary staff. ${ }^{34}$ The subscribers turned out in force to vote against this proposal. ${ }^{35}$

It is not clear why Bell's plan failed when the home-patient and inoculation schemes had met no opposition. The Trustees may have objected to a public institution being used by doctors for experiments, but a more political explanation is also possible. Of the three new physicians, only Bell was a prominent Dissenter with intellectual interests; Eason was a former army surgeon; Cowling may have been an Edinburgh graduate but he apparently took little interest in local affairs or scientific medicine. It may be that Bell raised the suspicions of the honorary surgeons and of the loyalist Trustees. By contrast, both Chorley and Latham were Oxford-educated and had strong county connexions, which the Manchester Tories may have found more appealing. After Bell's early death, Chorley and then Latham were appointed in his place.

The home-patient physicians were chiefly concerned with fever, which, during the 1780 s, became more and more important as a threat to the social and economic order. The first major local epidemic came in 1784, in Radcliffe near Bury, where the Peel family owned large spinning mills. An outbreak among textile workers led the landowner, Lord Grey de Wilton, to call in the Manchester magistrates. ${ }^{36}$ They asked the advice of the Infirmary physicians, including Percival, who now served as a consultant without regular duties. The physicians visited Radcliffe and their conclusions were published in the newspapers.

The textile workers themselves believed that the large, hot mills generated fever. The physicians reserved judgement but blamed excessive working and insanitary living conditions. Their report led to measures restricting the hours of work for parish apprentices. ${ }^{37}$ Robert Peel, offended at the interference, maintained that fever had spread from Preston where there were no mills and that for three months the Radcliffe outbreak had not affected any factory worker. ${ }^{38}$ Fever, through its association with appalling and controversial conditions of work, became a political issue.

That this issue proved no more contentious and that official medical opinion was undivided, may be attributed to the absence of any connexion with professional interest and to the relative unanimity with which the Manchester élite faced its

${ }^{33}$ Minutes of the Manchester Infirmary Quarterly Board, 22 January 1784.

34 Ibid., 25 September 1783.

$3 s$ Ibid., 18 December 1783.

36 Percival, op. cit., note 7 above, p. 5; Hope, op. cit., note 8 above, pp. 105-112. See also, W. Clerke, Thoughts upon the means of preserving the health of the poor by prevention and suppression of epidemic fevers, London, 1790, pp. 3-7; Anon., 'The putrid fever at Robert Peel's Radcliffe Mill', Notes and Queries, 1958, 103: 26-37; A. Meiklejohn, 'Outbreak of fever in Radcliffe cotton mills', Br. J. Ind. Med., $1959,16$.

${ }^{37}$ Hope, op. cit., note 8 above, p. 109.

38 Ibid., pp. 109-110. 
growing social problems in these years. Because large factories were still a new phenomenon, and because they were situated away from Manchester itself, they may have seemed a specific and limited problem, like jails or ships, not intricately bound up with the general texture of economic and social life. But with the end of the American wars and the expiry of Arkwright's patents, cotton spinning boomed and factories became much more common. Many buildings in Manchester were taken over for manufacturing and all branches of the cotton-textile trade experienced a rate of growth that was remarkable even by the standards of 1750-1780. This development of trade was associated with an increasing political self-confidence among manufacturers, whose economic interests were often divergent and linked in complex ways to older political and religious affiliations. It is this conjuncture of political and economic interests that we must now review as the immediate background to the 1790 revolution.

The first major mobilization came in 1784 , the same year as the Radcliffe epidemic. When Pitt imposed his "fustian tax", the Manchester manufacturers campaigned for its repeal, sending representatives to the London-based General Chamber of Manufacturers of Great Britain. ${ }^{39}$ In this agitation, the Manchester manufacturers were broadly united and proved successful. Their leader, Thomas Walker, became a local hero and developed an abiding distaste for Pitt. In 1786, as a fustian merchant, he opposed Pitt's proposed lowering of tariffs with France, but this time he was opposed by the majority of local cotton men. ${ }^{40}$ By 1788 , the calico lobby led by the Peels was in violent opposition to Walker's fustian lobby. ${ }^{41}$ Their antipathy found another expression in the slavery campaigns. Walker was a leading abolitionist, and was supported by most of the prominent Manchester Dissenters, including Percival and Bayley. ${ }^{42}$ Lawrence Peel helped to organize a petition against abolition. ${ }^{43}$

The anti-slavery campaign continued until mid-1789, when the Regency crisis became the major focus of local politics, and the abolitionists divided in their reaction to Pitt's tactics. Moderates such as Percival and his friend Thomas Henry, the apothecary, sided with local loyalists in congratulating Pitt on his handling of the crisis.4 Their declaration was countered by a younger radical group led by Thomas Walker, the Philips cousins, and Thomas Cooper, an immigrant lawyer who had dabbled in medicine and who had industrial interests. ${ }^{45}$

A year later, Manchester was the centre of agitation to repeal the Test and Corporation Acts, which kept Dissenters out of Oxford and Cambridge and certain

\footnotetext{
39 Frida Knight, The strange case of Thomas Walker, London, Lawrence \& Wishart, 1957, pp. 26-34. See also, Mary Hibbert Ware, Life and correspondence of the late Samuel Hibbert Ware. Manchester, 1882, pp. 99-101.

${ }^{40} \mathrm{~W}$. Bowden, Industrial society in England towards the end of the eighteenth century, London, Macmillan, 1965, pp. 184-185.

"Redford, op. cit., note 5 above, vol. 1, p. 194.

$42 \mathrm{E}$. M. Hunt, 'The north of England agitation for the abolition of the slave trade, 1780-1800', MA thesis, University of Manchester, 1959, pp. 23-24, 68.

${ }^{43}$ Ibid., pp. 85-90.

44 Manchester broadsheet, 13 January 1789, Manchester Central Reference Library Archives, f 1789/4/D.

45 A Manchester broadsheet of 8 January 1789, appealing for signatures, was followed by a broadsheet of 14 January 1789, containing several hundred names. See Manchester Central Reference Library Archives, $f$ 1789/4/D.
} 


\section{J. V. Pickstone and S. V. F. Butler}

public offices. ${ }^{46}$ The campaign had begun in the 1770 s, largely to remove restrictions on nonconformist clergy. When renewed in 1787, it was still London-based though more concerned with the rights of Dissenting laymen. But the failure of Bills in 1787 and in May 1789 led to the mobilization of provincial opinion, and by the end of 1789, in the direct wake of the French Revolution, the issue was highly controversial. Manchester opinion was strongly polarized. The moderate Dissenters, including many Baptists and Independents who were normally shy of politics, objected to a law which penalized loyal citizens, but they were suspicious of radicals such as Thomas Cooper and James Watt, for whom repeal was a step to greater social change. The local Tories opposed repeal, and in March 1790, when a third repeal Bill failed, they organized a "Church and King" club to celebrate. ${ }^{47}$ In opposition, the reformers set up a Constitutional Society to fight for democratic government; 4 Walker was its President, the Stewards included George Philips, Thomas Cooper, and George Lloyd. Lloyd, like Cooper, was a lawyer. George Philips, like Walker, was the son of a local merchant/manufacturer. Though Walker was an Anglican, he had become identified with the Dissenters' campaign.

\section{THE INFIRMARY DISPUTE, 1788-89}

By the late 1780s, though Whig and radical physicians were well represented in the Literary and Philosophical Society, they were peripheral to the Infirmary. John Mitchell, once assistant physician, was no longer on the staff. Bell, the most "progressive" of the full physicians elected in 1782, had died of fever in 1784. His successor was Dr Chorley, who left in December 1784 and was succeeded by Latham. When, in 1786, Latham returned to Oxford, the third physician's place was filled by Thomas White, who had been assisting his father Charles as an Infirmary surgeon. In the political disputes of the early 1790s, Thomas was to emerge as a leading Loyalist, chairing a meeting of the Society to Put Down Levellers. ${ }^{49}$

At about the same time as Thomas White joined the staff, George Tomlinson was appointed physician's clerk, to attend to the home-patients. ${ }^{30}$ The arduous work of home-visiting, first undertaken by the ambitious practitioners appointed as assistants in 1780, was now being shuffled off on to a paid junior resident.

Thus by 1787, the Halls and Whites filled four of the six honorary positions. Of the three honorary physicians, only Cowling, who was probably an Edinburgh graduate, might have passed as a "pure" physician. None of them was approaching retirement, and none had any developed interest in public health, though Eason was noted for

\footnotetext{
${ }^{4}$ On the national campaign for religious toleration see U.R.Q. Henriques, Religious toleration in England, 1787-1833, London, Routledge \& Kegan Paul, 1961, pp. 54-98, A. Goodwin, The friends of liberty: the English Democratic Movement in the age of the French Revolution, London, Hutchinson, 1979, pp. 65-98.

${ }^{47}$ A. Prentice, Historical sketches of Manchester, 1792-1832, London, 1851, p. 5.

${ }^{4} \mathrm{~T}$. Walker, $A$ review of some of the political events which have occurred in Manchester during the last five years: being a sequel to the trial of Thomas Walker and others, London, 1794, p. 15.

4 For details of White's appointment, see Minutes of the Manchester Infirmary Quarterly Board, 7 September 1786. For his involvement in the loyalist Society to Put Down Levellers, see Prentice, op. cit., note 47 above, pp. $422-423$.

so Minutes of the Manchester Infirmary General Board, 19 January 1786.
} 
devotion to the poor. ${ }^{51}$ Such a situation frustrated young physicians like the Scot, John Ferriar, ${ }^{32}$ who had graduated at Edinburgh in 1781 before settling in Manchester and becoming a close associate of Percival. Neither did it appeal to a surgeon like William Simmons, ${ }^{33}$ who came to Manchester in 1789 well qualified in midwifery and ready to challenge the Halls and the Whites.

Ferriar was a friend of Walker, Cooper, and the other radical leaders as they criticized and campaigned against the traditional rulers of Manchester. Their plans to "open-up" the town included its major charity, then dominated by surgeons linked with the Tory clique. They launched their Infirmary campaign at the end of 1788, when the agitation against slavery was already polarizing the local middle class. At the December Quarterly Board, they proposed to rescind Rule 13, which limited the size of the honorary staff, and to hold an election in March 1789 for a fourth physician and a fourth surgeon. ${ }^{34}$ These resolutions were subject to approval at the next Annual Board.

There is no doubt as to the source of this initiative. When the issue became public, eight Trustees who had attended the December meeting, gave their full support to the expansion. ${ }^{\text {ss }}$ These included Thomas Walker, Thomas Cooper, John Mitchell, Robert Philips, George Philips, and John Philips, Junior. The other two signatories were James Potter, a Unitarian, and David Yates, a Methodist. Similarly, there is no doubt about the opposition leaders. Charles White and Thomas White had both been present; they and the other medical staff loudly protested against the decision. ${ }^{56}$

A public debate, in newspapers and broadsheets, continued until the meeting in March. ${ }^{57}$ It was contemporary with the protest and counter-protest over the loyalist address of thanks to Pitt for his handling of the Regency crisis. Generally, the groupings were similar: seven of the eight trustees who supported expansion also protested against the address of thanks to Pitt. And most of those who wrote to the Mercury on 3 March 1789, suggesting that any future proposals for rule changes be advertised in advance, were loyal supporters of the Prime Minister. Of the fifty-eight opponents of expansion, twenty-nine are identifiably pro-Pitt, and only seven against.

If we consider the arguments for and against expansion, this congruence with general politics is understandable. ${ }^{38}$ The conservative case was simple: the previous arrangements had worked well and the medical men had not requested help; to force it upon them was to insult them. To abandon the rule would open the doors of the Infirmary to inexperienced and ignorant doctors elected by unwitting trustees.

The expansionist case was based on the duty of Trustees to make available to the

s1 Brockbank, op. cit., note 15 above, pp. 112-114.

32 Ibid., pp. 128-156.

${ }^{33}$ Ibid., pp. 170-181.

s4 Minutes of the Manchester Infirmary Quarterly Board, 10 December 1788.

ss Broadsheet signed by James Potter, John Mitchell, John Philips jr., David Yates, Robert Philips, Thomas Walker, George Philips, Thomas Cooper, 3 January 1789. Manchester Central Reference Library, MS $942.73001 \mathrm{HF}$.

s6 Minutes of the Manchester Infirmary Weekly Board, 22 December 1788, contain a letter from all the honorary staff.

${ }^{37}$ The meeting was held on 19 March 1789. See Manchester Mercury, 27 January, 10 February, 3 March, and 17 March 1789.

${ }^{58}$ Both sides of the issue are presented in a series of letters published in the Mercury, 17 March 1789. 


\section{J. V. Pickstone and S. V. F. Butler}

poor as much medical talent as possible. Because the Infirmary was not just a service but a means of improving medicine, to increase the access of physicians and surgeons would be to increase the medical talent of Manchester, both in the Infirmary and in private practice. Such an increase was not just desirable in principle, it was necessitated by the increase in quantity and range of the Infirmary services over the thirty-seven years since its foundation. This necessity was evidenced by the undue amount of work being devolved to the resident assistants (including the care of all home-patients). An expansion of the staff would be an act of respect to the existing doctors; it would remove an unfair burden from them and thus end the undue obligation of the Trustees to them.

In March, the Whites and the Halls mustered enough support to reverse the December decision by a vote of 114 to $62 .{ }^{39}$ However, though the radicals failed to break the hold of the established honorary staff, they did ensure the appointment of two assistant physicians to look after the home-patients. During the food shortages of 1788-89, a general subscription had to be raised in support of the poor. In these circumstances, it was difficult to oppose the addition of two home-patient physicians, who could take over some of the work from the hard-pressed physicians' clerk. On this question, the opposition of the Halls and Whites was defeated by the Trustees, who claimed that the Faculty did not control the Infirmary. ${ }^{60}$

Tomlinson, the physicians' clerk, obviously feared that the additional physicians would undermine his own position, and the following June offered to continue the work gratis. ${ }^{61}$ But a week later, George Philips gave notice to the Weekly Board of his intention to propose John Ferriar and George Bew for the home-physicians' appointments. ${ }^{62} \mathrm{Bew}$, a local apothecary-turned-physician, had been joint secretary to the Literary and Philosophical Society from 1781 to $1784 .^{63}$ Like Ferriar, he was a close associate of Percival. Both were appointed to the Infirmary in October 1789, and the decision was confirmed unanimously at the December Quarterly Board. ${ }^{64}$ The full physicians - Cowling, Eason and White - asserted their status by resigning their responsibilities to the home-patients, ${ }^{65}$ and at the December meeting new regulations concerning the home-patient service were drawn up, dividing the town into districts and allocating patients in an effort to ensure no further bickering between members of staff or between staff and Trustees. ${ }^{66}$ This renovation of the home-patients service came at a critical time. Typhus fever broke out in November 1789, and the epidemic continued through the winter, worsening again in April.67 Although Manchester suffered relatively slightly, the inhabitants were worried by accounts of virulent fever in surrounding towns.

\footnotetext{
39 Minutes of the Manchester Infirmary Quarterly Board, 19 March 1789.

60 Report of the 19 March meeting in the Manchester Mercury, 31 March, 1789.

'1 Minutes of the Manchester Infirmary Weekly Board, 15 June 1789; Minutes of the Manchester Infirmary Quarterly Board, 18 June 1789.

62 Minutes of the Manchester Infirmary Weekly Board, 22 June 1789.

${ }^{63}$ Brockbank, op. cit., note 15 above, pp. 157-158.

44 Minutes of the Manchester Infirmary Quarterly Board, 8 October and 24 December 1789.

cs Minutes of the Manchester Infirmary Weekly Board, 2 November 1789.

66 Minutes of the Manchester Infirmary Quarterly Board, 24 December 1789.

67 John Ferriar, 'Epidemic fever of 1789 and 1790', in Medical histories and reflections, vol. 1, Warrington, 1792, pp. 117-144, see especially pp. 118-119.
} 
As in 1784, the Bury district was badly affected and the authorities were alarmed. This time it was the Rector, Sir William Clerke, who called for Percival's help when faced with disease and unrest in an immigrant and unknown population. Percival assured him that regulation was possible and gave instructions, derived in part from Haygarth's Smallpox Society in Chester. ${ }^{68}$ The poor were provided with medical advice and cordials, whitewash and bed linen; the necessity of cleanliness was stressed; rewards were given for information about new cases and to families who kept the rules. ${ }^{69}$

The old system of poor relief through public charity and the parish was not sufficient for these novel problems of epidemic disease.. The fear of infection, of economic loss, and of political instability demanded that the poor should not be "left ignorantly to disseminate, to labour and fall prey to epidemic fever". ${ }^{70}$ Factories were private concerns and too remote from public scrutiny to be the primary focus of control measures; instead, a medical inspectorate was set up to police the whole community of the poor. ${ }^{71}$ The relief operations were funded and administered by those whose wealth derived from the labouring poor, in an effort to cement "general goodwill, and strengthen the general interest of society... [in] the knowledge of the necessity of mutual dependence". ${ }^{22}$ The 1789-90 epidemic underlined Percival's status as the local authority on fever, and it provided John Ferriar with material for his first essays on medical policing.

The appointment of additional Infirmary staff to care for fever patients must have encouraged members of the local profession in their efforts to open up the hospital. In the spring of the following year, William Simmons, the surgeon and man-midwife, who had been practising in Manchester for barely a year, wrote to the Trustees suggesting a further extension to the home-patient service. He offered to "attend in labour, such poor, married women, as are real objects of charity in all cases of difficulty where the midwife attending is incapable of delivering, and as it often happens, in such cases, that medical aid is required. I do also propose to attend them until they recover being allowed to call upon this charity for medicines as may be necessary". ${ }^{3} \mathrm{He}$ was at pains to stress the economy and social utility of his suggestion. Many women after childbirth developed puerperal fever and became homepatients; many of these cases would be prevented by "timely and proper assistance", so that, on balance, the cost to the charity would be negligible.

Extending the home-patient service in this way was a direct threat to the Halls and the Whites, who had dominated midwifery in Manchester. Obstetrics was an important branch of practice, in part because of the attachments formed between the surgeons and each growing family. By offering to act as man-midwife to the Infirmary, William Simmons was bidding for a share in this lucrative and fashionable business.

\footnotetext{
68 For details of Haygarth's Society see Buer, op. cit., note 23 above, pp. 185-186.

69 Clerke, op. cit., note 36 above, pp. 13-14, outlines the measures adopted.

70 Ibid., p. 23.

"Ibid., p. 21.

12 Ibid., p. 24.

${ }^{13}$ Simmons's letter was published in the Manchester Mercury, 11 May 1790, and is included in the Minutes of the Manchester Infirmary Weekly Board, 10 May 1790.
} 


\section{J. V. Pickstone and S. V. F. Butler}

The Whites and Halls reacted quickly. They maintained that Simmons's proposal would overstretch the resources of the Infirmary and in particular its apothecary's shop. While not disputing the worth of Simmons's suggestion, they argued that such a service would be best operated as a separate charity. ${ }^{74}$ They were obviously seriously concerned, challenging the would-be reformers to test their popular support in an independent venture. Presumably, they sensed that the inclusion of a midwifery service would be generally well regarded, so they could not be sure of keeping Simmons off the Infirmary staff. They took the one path guaranteed to safeguard their professional supremacy and organized a Lying-in Charity of their own. They counted on their positions and reputations attracting sufficient support, and they were not disappointed. On 5 May, the Charity was launched at a meeting in the Bridgewater Arms. ${ }^{75}$ This was followed by advertisements in the local press for subscriptions. ${ }^{76}$ On 21 May the first mother-to-be was "admitted", and by the end of 1790, eighty-seven women had been accepted as patients, of whom forty-seven had been delivered in their own homes, and forty remained "on the books"."

The Infirmary Board were evidently annoyed by this fait accompli. On 10 May, they published Simmons's letter together with White's reply, making the dispute public to the whole town. Before the Annual Board Meeting of 17 June, the Mercury carried numerous letters about the Infirmary disputes. ${ }^{78}$ Some discussed staffing, others concentrated on the treatment of home-patients, especially fever patients. A proposal that home-patients, when sufficiently recovered, should attend the Infirmary twice a week, like out-patients, aroused bitter opposition. "Moderatus" suggested that separate rooms could be set aside for the reception of home-patients, which would prevent out-patients contracting fever. "Mancuniensis", however, was more critical:

In my occasional Attendances at the Board of the Infirmary, I have often observed with concern the great Crowd of poor Persons collected in the Lobby of the house endangered not only of having their present diseases increased by a long and tedious Attendance in that cold situation but exposed to the contraction of new ones by Contagion conveyed in the Cloaths of a Number of people strongly impregnated with infectious miasms carried in them from the close and dirty rooms in which many of the sick persons who labour under Fevers are confined."

Echoing the honorary staff, he suggested that what was needed was an entirely new charity. Those who ran the Infirmary were well aware of the problem: six years later, James Hilton, the honorary secretary wrote: "It happened very often that in the great number of persons applying for relief at the Infirmary, many both In and Out Patients, were found on examination by their Physicians or Surgeons, to have feverish complaints, as well as those disorders for which they were recommended". ${ }^{80}$ The problem was well recognized because of the recent epidemic, but proffered solutions differed according to the political positions of the protagonists. "Mancuniensis",

14 The honorary staff's letter was published in the same issue of the Mercury as Simmons's letter.

75 J. H. Young, St Mary's Hospital, Manchester, 1790-1963, Edinburgh, Livingstone, 1964, pp. 1-13, describes the establishment of the hospital.

${ }^{76}$ Advertisement dated 8 May 1790 appeared in the Manchester Mercury, 11 May 1790, along with details of the 5 May meeting and a list of subscribers and officers.

7 Young, op. cit., note 75 above, p. 6.

"Manchester Mercury, 15 June 1790.

7 Ibid., letter signed Mancuniensis.

20 Letter in material concerning the Board of Health, University of London Library. (Microfilm copy in Manchester Central Reference Library.) 
in suggesting a separate charity, mentioned that the new Lying-in Charity could be merged with it, as could the medical services of the prison and the proposed new workhouse. Given the oligarchic control of the poor law machinery, such a link probably would have bound the new foundation into the traditional municipal establishment. Certainly, as in other towns, it would have created a junior institution, making the public health service subsidiary to in-patient care.

The controversies attracted large numbers to the Annual Board on 17 June. There, the question of accommodation for home-patients was again raised. The expansionists suggested that an extension could be built where home-patients, while kept entirely separate from in-patients, could receive treatment from the home-physicians. The suggestion was referred to a committee to consider the running of the public baths, and this committee became the spearhead of the expansionist effort. ${ }^{81}$ The tensions between the factions were evident. William Simmons was thanked conspicuously by the Trustees, and, over the objections of the surgeons, the letters were sent to the press. In the Manchester Mercury of 15 June, a letter from the Faculty had been published blaming the Treasurer for the discord between the medical staff and Trustees. At the Annual Meeting, however, the Treasurer, Henry Worrall, was given a vote of confidence and the honorary staff thus implicitly censured. Significantly, Ferriar and Bew firmly dissociated themselves from the attack on Worrall both in the press and at the meeting. They took the side of the lay majority against the Whites and the Halls.

The composition of the committee appointed by the 17 June meeting and that of the committee appointed later, is crucial to our understanding of the dynamics of reform. ${ }^{82}$ As would be expected, all the honorary staff, including Ferriar, Bew, and Percival, were members, and so were the leading laymen of the Infirmary: Worrall, Massey, Thomas Butterworth Bayley, and John Whittenbury, Treasurer of the Lunatic Hospital. Among these, the balance of opinion was probably conservative. But the three other members - George Lloyd, James Potter, and Dr Mitchell - were all radicals, prominent a few months earlier in the fight against the Test laws.

The committee had been asked to prepare a report for 4 July. On the 22nd, a Special Board meeting was held but no firm proposals were made though the committee had submitted a preliminary report affirming the need for reorganization. ${ }^{83}$ Expansion was clearly in the air, for Robert Darbey, the former resident apothecary, now a graduate, offered his services as physician to the home-patients. ${ }^{84}$ The meeting also acknowledged three letters from surgeons applying for Infirmary posts. ${ }^{85}$

\footnotetext{
${ }^{21}$ Minutes of the Manchester Infirmary Quarterly Board, 17 June 1790; Manchester Mercury, 22 June 1790.

$\$ 2$ We used several petitions, each with long lists of names, to work out the political anatomy of these committees. For those supporting the Dissenters' cause: a petition in support of the Test and Corporation Acts campaign in the Manchester Mercury, 3 February 1790. For Dissenters loyal to the established constitution: a petition in the Manchester Herald, 29 December 1792. Inclusion in any one of three petitions in the Manchester Herald, 2 June, 6 December, and 22 December 1792, was used to indicate loyalist political views. We are also indebted to the Rev. Henry Rack for additional information from church lists.

${ }^{83}$ Manchester Mercury, 27 July 1790.

24 Minutes of the Manchester Infirmary Weekly Board, 20 June 1790.

ss Minutes of the Manchester Infirmary Quarterly Board, 22 July 1790. The surgeons were John Bill, Robert Killer, and William Brigham. Brigham referred to a dispensary appointment, while Killer indicated his willingness to act as medical officer to the home-patients. See also, Manchester Mercury, 20 July 1790,
} 


\section{J. V. Pickstone and S. V. F. Butler}

No decison about expansion was taken in July. Instead, a second committee was appointed with a broad mandate to look into "everything relative to the Infirmary, Lunatic Hospital, Home Patients and Baths as well as any extension of the Charity" ${ }^{86}$ Twenty individuals were selected to join those who had already served on the 17 June committee. They included a number of doctors - Robert Darbey, William Simmons, George Tomlinson, John Killer, and the apothecaries Thomas Henry and Edward Deacon - most of whom had direct personal interest in expansion. The extended committee also included a number of conservative laymen, together with a further group of prominent radicals, including Thomas Walker and George Philips. If, to the doctors interested in expansion, we add all those committee members known to be active in Dissenting or anti-Pitt campaigns, the total is twenty out of thirty-seven. Those known to be loyalists or opponents of Infirmary expansion number fourteen: the remaining three individuals have proved difficult to trace.

As the committee deliberated, ambitious medical men anticipated expansion. During the first week in August, the Mercury published six letters from surgeons canvassing for the possible extra posts, although no vacancies were publicized. ${ }^{87}$ The position of the honorary staff, who had publicly opposed expansion, was becoming increasingly difficult. On 2 August, Eason resigned, and the announcement prompted three applications, from Ferriar, Bew, and Darbey. A week later, Charles White resigned, complaining about "the attempts ... very unjustifiable ... to overturn the constitution of the Infirmary as originally established". ${ }^{88}$ His letter was accompanied by the resignations of the two Halls. It was by now quite clear which side the July committee's report would favour. On 3 September, the committee sent copies of the report to subscribers in preparation for the Quarterly Board to be held on 23 September.

The committee recommended that Rule 13 should be rescinded. They also advised that the home-patient service be fully integrated with the other work of the physicians; that an extension to the buildings be erected in the grounds to accommodate out- and home-patients; and that the number of physicians and that of surgeons be increased to six. The report maintained that "it is desirable that these Charities should be conducted on a broad liberal plan, totally disregarding the private views or wishes of such individuals as are now in office, or of such as may later be so, and that the real good of the Charities, and the Community, ought to be their sole object". ${ }^{89}$

During the three weeks between the publication of the report and the meeting at which it was to be discussed, letters appeared in the press exploring both sides of the disputes. Most of the arguments had been used in the spring of 1789, but now the conservatives could also claim that the Infirmary would not easily replace the old surgeons. No doubt the honorary staff had hoped by resigning to wreck the expansionist plan and reassert their influence over the hospital. But the abundance of able applicants soon dashed their hopes. The most notable among them was Alex Taylor,

\footnotetext{
which contains letters of application from Richard Nanfran, George Tomlinson, William Simmons, and Michael Ward.

*6 Minutes of the Manchester Infirmary Quarterly Board, 22 July 1790.

27 Manchester Mercury, 10 August 1790.

Ibid.

"The committee's report was published in the Manchester Mercury, 7 September 1790.
} 
an Edinburgh-trained physician with a considerable reputation as a lithotomist. ${ }^{90}$ The other applicants were mostly local, but they all had good reputations as sound operators.

In 1789, the honorary staff had retained firm control of developments: by August 1790, the Trustees were urged to resist coercion by the honorary staff. Just before the public meeting, the Henshaw brothers, successful manufacturers in Oldham, wrote to the committee complimenting them on the cordial spirit in which the affair had been conducted and asserting that opposition would come only from those who rated private interests above public. ${ }^{91}$ By opening the hospital to more medical men, the professional hierarchy would be broken somewhat and professional practice would become more competitive. In this way, not only would the poor be provided with medical care gratis but the middling ranks would benefit from a better professional service.

That the issues were thought to be important is clear from the large turn-out at the crucial 23 September meeting. ${ }^{92}$ Over 350 subscribers met to debate and vote on the proposal to increase the medical and surgical staff. It was an impressive victory for the expansionists: 217 voted for the motion, only 142 against. There were, by now, four candidates for the four vacant physicians' posts, and Ferriar, Bew, Darbey, and Le Sassier, all of whom had Scottish degrees, were appointed. Cowling and Thomas White continued as honorary physicians for some months before resigning and were then replaced by Joshua Parr and Samuel Argent Bardsley, both Leiden graduates and strangers to Manchester. ${ }^{93}$

Competition for the honorary surgeons' posts was much fiercer. Ten candidates presented themselves. Of the six elected, only two - Robert Killer and John Bill - were local surgeons. Alexander Taylor had trained in Scotland; William Simmons had attended the Hunters' School in London; Gavin Hamilton had acquired his skills serving in the army; Michael Ward was physician to the Buxton Bath charity.

The increase in staff was the beginning of a total transformation of the hospital. The September meeting sanctioned a new building providing a dispensary and additional wards, including some for patients who developed fever while in the Infirmary. The dispensary was opened in 1792 , financed in part by sermons preached by clergymen sympathetic to the extended charity.

The committee, which had met over the summer to draft proposals for reform, was reappointed, and over the following months prepared more detailed recommendations. In March 1791, they revised the arrangements for nursing, imposing stricter discipline in an attempt to attract more respectable women. They also worked out a new code of rights and duties for patients.94

Simmons, now an honorary surgeon, saw his proposal implemented despite the

so Brockbank, op. cit., note 15 above, pp. 184-185.

"Manchester Mercury, 21 September 1790, letter dated 16 September 1790. The Henshaw brothers were conspicuously thanked at the September meeting for their support to the Charity, Minutes of the Manchester Infirmary Quarterly Board, 23 September 1790..

22 Ibid.

${ }^{93}$ For biographical details of the new medical and surgical staff see Brockbank, op. cit., note 15 above, pp. 127-190.

* Minutes of the Manchester Infirmary Quarterly Board, 24 March 1791. Rules of the government of the Infirmary, Lunatic-Hospital, and Public Baths in Manchester, Manchester, 1791. 


\section{J. V. Pickstone and S. V. F. Butler}

existence of the Whites' new Charity. But midwifery never became an important section of the Infirmary; the Lying-in Charity soon established a dominant role in the care of the pregnant poor.

The Infirmary Trustees were keen to supervise the physicians and surgeons and insisted that their attendances be recorded. In 1792, they asked Thomas Percival for detailed guidance on acceptable professional behaviour to ensure that the embarrassing arguments of 1790 did not happen again. Percival's advice was duly incorporated into the Infirmary rules, and he published a version privately in $1794 .^{95}$ In 1802 , a second edition became generally available as Medical ethics, a work of great influence both in Britain and especially in the United States.

The Trustees also wanted to advance medicine. A library was organized; full case records were required; the anatomical collection was catalogued by the apothecary. The new surgeons indicated their co-operation by renouncing their rights to apprentices' fees. ${ }^{96}$ In return, the Trustees contracted to purchase instruments for the surgeons.97 The Infirmary was no longer to be an agency for the advancement of private interests, but rather the nucleus of a professional community. John Ferriar noted in 1792, that "the extended plan ... affords the most favourable opportunities to a diligent observer, for ascertaining with precision many facts in the history of diseases, and for appreciating the value of established methods of cure". Echoing the Henshaws' belief that the public as a whole would benefit, Ferriar continued: "Some part of the fruits of such advantages should therefore revert to the public, in acknowledgment of the good it bestows. And something may be added to the stock of science by unwearied attention to a considerable number of patients, indiscriminately taken, in a great town".98

The reforms were popular: many new subscribers were enrolled, and many others increased their subscriptions. At the Annual Board in 1791, the Trustees congratulated themselves on the quality of the hospital, and the arrangements in the dispensary. They concluded that "the sick poor of this town really enjoy advantages in medical assistance, which are often out of reach of persons in the middle rank of life".99

\section{REVOLUTION IN RETROSPECT}

It has not been difficult to demonstrate the role of Manchester radicals and Whigs in the hospital expansion campaign. The opposition came from the Whites, the Halls, and their fellow Tory Anglicans. When the issue came to a head in September 1790, the conflict over Dissenters' rights precipitated the Church and King Club on the one side and the Constitutional Society on the other. That this political polarization was also a feature of the Infirmary dispute is clear; that it was decisive in the voting pattern is more difficult to establish.

${ }_{95}$ T. Percival, Medical ethics, in the Works, op. cit., note 8 above, vol. 2, pp. 355-572. For the origins of the Ethics, see 'Preface', pp. 367-371, and on the distribution of the original, privately printed version see 'Notes and illustrations', pp. 482-483.

* Minutes of the Manchester Infirmary Weekly Board, 11 October 1790.

97 Ibid., 3 January 1791.

98 Ferriar, op. cit., note 67 above, vol. 1 (1792), 'Preface', pp. i-ii.

- Annual report of the Manchester Infirmary, June 1791. 


\section{The politics of medicine in Manchester, 1788-1792}

We once hoped that sufficient of the Infirmary voters could be identified among supporters and opponents of that and other contemporary campaigns to allow a plausible reconstruction of the September 1790 vote. In fact, because we do not know which of the voters supported expansion and because many who publicly aligned themselves in various disputes did not in fact vote, we are left with many voters about whom we know nothing relevant. At the level of the "common subscriber", we cannot demonstrate statistically the significance of political or religious allegiances.

Other explanations are possible. When fever was a public problem and potential Infirmary physicians were offering a solution, an unpolitical public might prefer the expansion of the staff. The September 1790 meeting was also an election, and supporters of the various candidates may have favoured expansion simply out of friendship to individuals who stood to gain thereby. Undoubtedly, fever was more influential after the 1789-90 epidemic than it had been when the expansionist campaign suffered earlier defeats. Undoubtedly too, the existing Infirmary staff, by resigning their posts, had not only forfeited some support, they had unleashed a mass canvass of subscribers by those who hoped for appointment. Unfortunately, it is practically impossible to assess the significance of these reasons for supporting expansion. We can, however, get more information, especially about the attitudes of religious groups, by studying the responses to the Infirmary revolution.

As we would expect, the proportion of reformers among those attending Infirmary Boards increased markedly. At the Quarterly Board of November 1790, there were twenty-three known reformers and only ten known loyalists in a total of thirty-seven. The core of Anglican reaction, the Collegiate Church clergy, continued to snipe at the expansionists. When asked in 1792 to preach a sermon for the Infirmary funds, they declined, ${ }^{100}$ supposedly because they disapproved of the hospital expenditure having exceeded the income. The Trustees placed them (in absentia) on a committee to investigate the Infirmary affairs, and publicly rebutted the suggestions of extravagance. ${ }^{101}$

A very different response came from the evangelical wing of the Anglican church, from the Methodists associated with that wing, and from some of the Independents. The evidence strongly suggests that members of these groups have given important support to the Infirmary expansion and may well have converted a radical campaign into a majority cause.

In looking to Anglican evangelicals, we do little more than provide another instance supporting the well-known generalization that social reforms around 1800 were promoted by rationalists, such as the Unitarians, on the one hand, and evangelicals on the other. Less has been written about Methodist involvement, and local studies can give a socio-economic context otherwise unavailable. In the paradigm case of industrializing Manchester, it is particularly important to examine the dynamics of philanthropy.

In 1790, as the Infirmary issue was coming to the boil, the Reverend Cornelius Bayley of the St James Church was setting up a fund "for the sick and indigent of

100 Minutes of the Manchester Infirmary Quarterly Board, 22 March 1792.

101 Minutes of the Manchester Infirmary adjourned Quarterly Board, 19 April 1792. 


\section{J. V. Pickstone and S. V. F. Butler}

every denomination, and particularly the sick-poor Stranger". ${ }^{102}$ Bayley had previously been a preacher to the Methodist chapel on Oldham Street, and he was a close associate of John Wesley. ${ }^{103} \mathrm{His}$ humble origins aroused the scorn of the high-church clergy attached to the College, but he was a success among the businessmen in the fashionable residential district around his new church. His was a congregation of "rich sinners", many of whom also attended the Methodist chapel.

Bayley's charitable society undoubtedly owed its origin to the Stranger's Friend Society initiated in Bristol in 1789 by Wesley himself and by Dr Adam Clarke, another Wesleyan leader. ${ }^{104}$ The charity sought out and relieved those poor who lacked settlement rights under the Elizabethan Poor Law. When Clarke, who had medical interests, moved to Dublin, he began a similar society there. For the most part, Methodists kept their philanthropy within their own congregations; Strangers' Friend Societies were a conspicuous exception. In 1791, Clarke returned to England, and because his health was poor, he was assigned to the circuit that included the Buxton Baths. In March 1791, at Oldham Street Chapel, he set up a Strangers' Friend Society for Manchester and this soon superseded Bayley's charity. ${ }^{105}$

Clarke's society was a success: it continued to be dominated by Methodists but it attracted general support. Its work was particularly important during the crises of 1792 and 1795-96, when the Society co-operated with the parish officials in charge of poor relief. It linked with the Infirmary in the first of these crises, when lists of homepatients were given to the Society, who checked their need for medical charity and relieved those who were strangers. In 1796, when a fever hospital was begun, the Methodists formed further links with the Infirmary. ${ }^{106}$

It seems likely that the attitudes shown in 1791-92 were also there in 1790, and that Methodist and Anglican evangelicals may well have given appreciable support to the Infirmary campaign. Bayley was present at the September 1790 meeting, and in 1792 , he praised the extensions in a sermon for the benefit of the Infirmary funds. ${ }^{107}$ That Bayley was preaching in the Collegiate Church, the home of high-church Tories who had refused to oblige, suggests that the evangelical faction was becoming more prominent and was closely identified with the reformed Infirmary. Indeed, in 1791-92, the Tory Anglicans were somewhat eclipsed; Cornelius Bayley was using their church for a cause they had opposed; Thomas Walker, on the vote of the Court Leet, was Boroughreeve.

The letter from the Henshaw brothers that gave support to expansion just before the September 1790 meeting may be relevant here. The Henshaws were self-made manufacturers from Oldham, known more as Christian philanthropists than as religious or political leaders. The references to their letter made by Infirmary expansionists may have secured the support of others interested more in charity than in medical politics or reform.

102 Rules of the Benevolent Society instituted at Manchester, 11 July 1790.

${ }^{103}$ E. A. Rose, 'Cornelius Bayley and the Manchester Methodists', Proc. Wesley Hist. Soc., 1964, 34: $153-158$.

104 J. Everett, Adam Clarke portrayed, London, 1843, vol. 1, p. 281.

105 Ibid., pp. 307-308. See also, Hindle, op. cit., note 6 above, pp. 78-89.

106 Minutes of the Manchester Infirmary Quarterly Board, 20 December 1792.

107 Bayley, op. cit., note 1 above. 
We should not underestimate the significance of the evangelicals and Wesleyans. They were rarely active in local politics, but they did have a great deal of money. In 1795, a Methodist minister visiting Manchester to attend the Conference, wrote to his wife:

I am sorry you have heard of mobs in this place. But you need not be uneasy: all is peace and quietness .... If it were otherwise, there would be no danger of the preachers being abused. There is, perhaps, no town in the kingdom where Methodists are so much in favour with the populace as in Manchester. The extraordinary beneficence of our people is universally known. It is not long since they gave away $£ 200$ at once. When the last collection was made by the gentlemen of the town for the relief of the poor, our people were employed to visit and relieve them. ${ }^{106}$

The essence of Wesleyan charity was the off-loading of superfluous wealth which otherwise burdened the soul. ${ }^{109}$ Such givers may well have welcomed well-organized charities like the Infirmary, which would carry the responsibility for using the donations.

That certainly was the appeal made in an Infirmary sermon of 1792 by Thomas Kennedy, the first minister of the Mosley Street Independent Chapel, a congregation dominated by Scots. Kennedy preached that "it is the grace of the gospel alone ... that teaches us to feel, and to alleviate the distress of our fellow citizens". He then told his hearers to rely on the wise administration of the expanded Infirmary, "while you pursue your own private business with undivided attention; they, as your almoners, disperse your charity with a prudent hand ...". ${ }^{110}$ The boom of the 1790 s had built up considerable sums for dispersal. By 1790, Methodists, low Anglicans, and Independents were looking for prudent hands.

A few such men were already connected with the Infirmary and some were associated with the Infirmary expansionists in the anti-slavery agitation. David Yates, a merchant and leading Methodist, was Treasurer of the Lunatic Hospital and one of the originators of the Infirmary expansion campaign. Richard Barlow, of Oldham Street Chapel and St James, also gave support in 1788 when the radicals attempted to change Rule 13. Barlow served on the June 1790 Committee which advocated expansion; the next year he was one of the organizers of the Strangers' Friend Society. ${ }^{111}$ The Reverend Adam Clarke was a major figure in the anti-slavery campaign and so was the Reverend Samuel Bradburn, another prominent Methodist preacher who was closely identified with radical causes. ${ }^{112}$ We should be wary of attributing to the Wesleyan leadership of 1790 the politics of Jabez Bunting in the Napoleonic period. We might instead remember that Jabez called his son Thomas Percival Bunting, in honour of the man he had once served as a secretarial assistant. ${ }^{113}$

There is then, every reason to believe that the radical and Whig leadership in the Infirmary campaign gained valuable support from evangelicals of various denomina-

\footnotetext{
100 W. Entwistle, Memoir of the Rev. Joseph Entwistle, 1848, p. 133.

100 Wesley's sermon on 'The use of money' is quoted in G. D. Hall, 'Congregationalists, Methodists and Lancashire nonconformity, 1790-1907', MA thesis, University of Liverpool, 1974, pp. 69-70.

$110 \mathrm{~T}$. Kennedy, A sermon preached in the Independent Chapel, Mosley Street, Manchester, for the benefit of the Infirmary, Dispensary and Lunatic Hospital and Asylum, Manchester, 1792, p. 25.

11 Everett, op. cit., note 104 above, vol. 1, p. 308.

112 Ibid.

113 DNB; Jabez Bunting (1779-1858) was taken into Percival's home for four years in the 1790s as medical pupil and amanuensis.
} 


\section{J.V. Pickstone and S. V. F. Butler}

tions, then emerging as a significant sector of the Manchester middle class. It remains for us to discuss briefly the consequences of their success. What did the Infirmary revolution achieve?

By directing attention to the problem of public health, the revolution laid a basis for the treatment of fever in the massive epidemics of the 1790s. In those years especially, enormous numbers of patients were visited at home by the physicians of the Infirmary: 2,500 in $1792,4,200$ in 1796 , and 5,000 in 1801. It is difficult to know how effective these visits were in reducing mortality or easing discomfort, but if medical charities may be judged by the extent to which they make the best medical advice available to the poor, then the Manchester Infirmary was remarkably successful. Without the revolution, most of the poor would almost certainly have been visited only by the junior residents - the physicians' clerks.

But there is a paradox here. In some of the worst years of destitution and typhus, there were only three honorary physicians attached to the Infirmary. Between 1795 and 1797, Drs Ferriar, Holme, and Bardsley carried the work between them, while the other posts were unfilled, apparently for want of candidates. We cannot claim that six honorary physicians were absolutely necessary, even when the load on the homepatient service vastly exceeded anything imaged in 1790 , but very few physicians would have borne the load that Ferriar and his associates carried.

On the surgical side, the existence of six positions proved even more problematical. There was no shortage of surgeons, but there were not enough operations to satisfy them all. In the following years, according to the recollections of S. A. Bardsley, the physician, many of the Infirmary surgeons complained of insufficient operative experience. ${ }^{114}$ Bardsley maintained that six physicians and six surgeons had been too many in the 1790s; the number six had been chosen to fit the number of weekdays.

Bardsley's opinion has to be weighed against the common practice of Infirmaries and the hopes of the 1790 reformers. Undoubtedly, as the growth of population brought more and more patients to Infirmaries, the common practice in Manchester and elsewhere was not to increase the honorary staff but to reduce home visiting, devolve more work to junior residents, and, if necessary, expand the medical staff at that level. After 1790, there was no increase in the honorary staff at Manchester Infirmary until the growth of specialist departments at the end of the nineteenth century. By this standard, Bardsley may well have been right to query the need for the increase in 1790. But that is to accept the necessity and advantage of the medical hierarchies produced in voluntary hospitals and the marked division between consultants in the hospitals and general practitioners outside. One of the aims of the 1790 reformers was to reduce that division and allow a larger proportion of the town's doctors to have some experience of infirmary work.

It may be that the discontent among surgeons that Bardsley mentioned was also a factor in a series of disputes at the Infirmary in the years after 1800.115 These were largely about the relative powers of medical men and lay Trustees and were partly consequences of 1790 . Then, the expansionist physicians had relied on extensive lay

\footnotetext{
114 Manchester Mercury, 27 April 1827. Bardsley was arguing in opposition to another proposal to increase the honorary staff.

${ }^{115}$ Discussed in forthcoming book by J. V. Pickstone on hospitals in the Manchester region 1750-1948.
} 


\section{The politics of medicine in Manchester, 1788-1792}

support to overcome the resistance of entrenched surgeons accustomed to effective if not formal power. One of the results of 1790 seems to have been an increase in the relative power of laymen, especially of the Treasurer, J. L. Philips. He had considerable respect for Ferriar and the leading physicians, but, at least in the 1800s, he had less time for surgeons whom he regarded as self-serving. The reformers had wanted a more open Infirmary, some of the later surgeons found that uncomfortable.

Perhaps the best-known consequence of the 1790 revolution was the 1796 House of Recovery and the associated Board of Health. ${ }^{116}$ In many ways, the struggles to found the fever hospital were a re-enactment of the 1788-90 disputes; those who wanted a fever hospital to reduce the spread of disease through overcrowded houses and lodgings were led by Percival, Ferriar, and T. B. Bayley; opposition came from the Whites and the Tory loyalists. But the popular success of the Infirmary expansion and the increasing severity of fever epidemics eased the path of the reformers.

By this time, the radical group which had begun the 1790 campaign had been suppressed; Thomas Cooper had fled to America; Thomas Walker had been prosecuted for treason and his business ruined; the other middle-class radicals of Manchester were lying low. By 1800, little remained of their reforming energy. The fever hospital continued, but nothing was done to attack the causes of fever. Ferriar's suggestions, which included the regular inspection of lodging-houses, were forgotten. Yet the House of Recovery remained important. As the first fever hospital to be built in Britain, it was widely imitated.

\section{CONCLUSION}

The House of Recovery and Percival's Medical ethics point to the uniqueness of the medical politics of Manchester in the late eighteenth century. In 1752, when the Infirmary was founded, Manchester had been a late-developer among the county towns of England: by the 1790s, it pioneered, because economic growth was creating a new social order. Of course, to understand fully the peculiarities of Manchester, we need more comparative studies, detailing the development of medical charities in other towns. But the one study we do have - Charles Webster's comparison of Manchester and Newcastle ${ }^{117}$ - does confirm that the Manchester medical reformers were indeed uncommonly successful in turning a traditional Infirmary into a comprehensive medical service. In this essay we have further explored the local context to discover how and why these reforms succeeded.

The answer is complex, involving several layers of political and social action, medical and lay; it is also, we hope, correspondingly illuminating. In a single institution we can follow the interactions of various overlapping groups - professional, political, and religious - which were the local components of important national "movements". We can begin to see how voluntary hospitals were related to the public health movement; how radicals and evangelicals might co-operate; how professional competition might be political; how the pressures of new industry could reinforce the

116 F. Renaud, $A$ short history of the House of Recovery, Manchester, 1885; J. Ferriar, 'Account of the establishment of fever wards in Manchester', in Medical histories, op. cit., note 67 above, vol. 3, pp. 43-92; Proceedings of the Board of Health of Manchester, Manchester, 1806.

117 Webster, op. cit., note 2 above. 


\section{J. V. Pickstone and S. V. F. Butler}

social and medical problems caused by poor harvests. We can begin to see "medicine" in context.

It is clear that the centre of the Infirmary dispute was the move to increase the honorary staff. Percival, in 1781, had recruited four assistant physicians who had begun the visiting service. In 1789, his associates, Ferriar and Bew, with the backing of local radicals, were made assistant physicians. It was not too difficult to create junior appointments, especially for work that did not attract the senior staff. But senior positions, or positions directly challenging the local surgeons, prompted different responses. When William Simmons challenged the Halls and Whites over midwifery, when they had already lost ground to the supporters of Ferriar and Bew, the reaction was much more dramatic.

At this level, the Infirmary dispute was a consequence of the migration of wellqualified professionals into a town where the Infirmary was dominated by two local surgical families. The normal result of such immigration was, we would guess, that the immigrants would establish a subsidiary charity. In Manchester, it was the established staff who finished up in an accessory institution.

They did so because the Infirmary was a relatively democratic organization. Issues which aroused the subscribers were decided by votes numbered in hundreds - a larger electorate than the manorial and parochial authorities. Those who objected to the power of the surgeons and their friends had means available to challenge it. But that meant mobilizing hundreds of subscribers prepared to vote against the status quo and prepared to offend an entrenched honorary staff, some of whom were distinguished, both as practitioners and as townsmen.

We have suggested that such a mobilization was possible, in 1790 though not in 1789, because the Infirmary issue became aligned with other issues in Manchester during a period of extraordinary political activity. In the Abolition debate and the Test and Corporation Acts campaign, the Whig and radical leaders gained wide support, and some of the radicals, especially Thomas Walker, established themselves as a major challenge to the local Tory oligarchy. The national issues were lost in Parliament; the Infirmary campaign could be won by a local vote. It seems that on the Infirmary question, as on slavery and Dissenters' rights, many previously nonpolitical Nonconformists and evangelical Anglicans were prepared to follow the Whig and radical leaders.

Some followed because they were themselves becoming interested in reaching out to the poor. Evangelicals and Methodists like Cornelius Bayley and Adam Clarke made careful, inquiring philanthropy part of their mission. The "rich sinners" of Bayley's congregation saw charity securing their influence during threatening times.

Epidemic disease was also a threat and its control required expertise. If the fever outbreaks of 1784 and 1789 had made the danger clear, they had also established Percival and Ferriar as authorities on medical police. These physicians, like their friend and magistrate T. B. Bayley, were needed at times of civic distress. The homevisiting undertaken by Ferriar and Bew during 1789 may well have impressed subscribers; they were acting out the expansionists' claim that the Infirmary services should be provided by experienced doctors not by paid juniors.

But the Infirmary campaign was not generally presented as a fight for better 
services to the poor; it was a struggle against old monopolies. As such it was a typical reform movement, part of the fight against "old corruption"."18 Manchester had been dominated by a Tory clique and the Infirmary staffing was part of that domination. To reform the Infirmary was to advance the public interest against the private interests of the existing staff. In 1790, liberty and equality were not yet frightening and the prospect of medical bills reduced by competition was an additional inducement to middling men. For these reasons, and to exercise their patronage in the choice of new staff, over two hundred subscribers gave their votes for the Infirmary revolution.

Some of the consequences are medical history. Percival's Medical ethics and the Manchester House of Recovery have become standard items in chronicles of public health and medicine. In this essay, we have tried to show that they can only be fully understood within a particular fragment of urban history. They were the fruits of 1790, when medical politics were for a while central to the politics of-Manchester.

110 E. P. Thompson, 'The peculiarities of the English' (1965), in The poverty of theory, London, 1968, pp. 35-91. See also, W. R. Ward, Religion and Society in England, 1796-1850. London, 1972, pp. $21-53$. 